\title{
Эксакусто Т.В. Проблема обеспечения социально-психологической безопасности личности
}

В статье подчеркивается, что в связи с современными условиями актуальным становится изучение психологической безопасности посредством исследования системы межличностных отношений. Поскольку психологическая безопасность в межличностных отношениях тем выше, чем лучше люди знают и понимают друг друга в группе, то возникает необходимость говорить о сочиально-психологической безопасности личности. Отмечается, что реализация системы отношений человека осуществляется посредством общения. Эффективность организации процесса общения во многом определяет систему межличностных отношений, а, следовательно - сочиально-психологическую безопасность людей. Соответственно, подчеркивается, что для обеспечения сочиально-психологической безопасности личности особое значение приобретает изучение феномена затрудненного общения, различных форм его проявления, психологических детерминант. Показано, что анализ этих проблем позволит разработать конкретные практические рекомендации по оптимизации межличностных отношений, что в конечном итоге будет способствовать развитию социально-психологической безопасности личности.

Ключевые слова: безопасность, сочиально-психологическая безопасность личности, характеристики социально-психологической безопасности, межличностные отношения, затрудненное общение, субъект затрудненного общения, обеспечение сочиально-психологической безопасности.

Принцип необходимости обеспечения собственной безопасности лежит в основе существования всех социальных систем и отдельно взятого человека. Этот принцип, связан с потребностями системы (равно как и человека) и ее элементов в выживании и дальнейшем (прогрессивном) развитии. Его содержанием является сознательная деятельность людей, направленная на снижение дезорганизующего влияния внешней и внутренней среды [2]. Проблема безопасности становится все более актуальной в современном обществе. Обусловлено это целым рядом причин: нестабильностью экономической, политической, социальной ситуации; наличием срессогенных и психогенных воздействий различного генеза; ростом чрезвычайных ситуаций техногенного характера; слабой психологической защищенностью личности.

Понятие безопасности рассматривается исходя из различных оснований. Как отмечается в ряде исследований (И.А. Баева, Г.В. Грачев, В.А. Дмитриевский, Н.А. Лызь, Т.М. Краснянская и многие другие) безопасность рассматривается, прежде всего, с точки зрения различных сфер ее проявления: экология (влияние на безопасность экологической среды), социум (влияние на безопасность 
общественно-политических и социально-экономических явлений), информационная среда (влияние процессов массового сознания, системы ценностных ориентаций и нравственных норм, декларируемых в обществе через (МИ), производство и средства технического прогресса (влияние промышленных технологий, сложных (высокоорганизованных) орудий труда). Одним из актуальных направлений в исследовании безопасности личности становится изучение психологической безопасности. При этом подчеркивается, что психологическая безопасность есть (Краснянская Т.М.):

- защищенность личности, сохранение ее целостности, возможность ее развития;

- удовлетворенность настоящим, уверенность в будущем;

- условия жизнедеятельности, не способствующие нарушению целостности личности, адаптивности ее функционирования;

- отсутствие страха или тревоги в отношении удовлетворения собственных настоящих и будущих потребностей;

- состояние защищенности интересов;

- защищенность сознания от воздействий против воли и желания человека изменять психические состояния, психологические характеристики и поведения и др.

При всем многообразии исследований психологической безопасности личности и особенностей ее проявления (в образовании, воспитании, профессиональной сфере и т.п.) эта проблема остается малоизученной с точки зрения межличностных отношений и общения. Однако, рост социального неблагополучия, поляризация общества (выделение социальных классов с разным экономическим статусом), рост преступности (терроризм, мошенничество, преступления против личности), снижение частоты и эффективности межличностных контактов приводит к тому, что человек испытывает все большую социальную незащищенность. Соответственно, с ростом неблагоприятных социальных условий растет число людей, которые характеризуются неудовлетворенностью потребности в социальной безопасности, что приводит к снижению удовлетворенности настоящим и отсутствию уверенности в будущем; к разрушению целостности личности, росту страха и тревоги; снижению устойчивости к неблагоприятным воздействиям.

Таким образом, очевидно, что в современных условиях все более актуальным становится изучение психологической безопасности посредством исследования системы социальных и, прежде всего, межличностных отношений.

В соответствие с Концепцией безопасности страны обеспечение безопасности должно осуществляется на следующих уровнях: межличностном, региональном, национальном (государство, страна) и международном [2]. При этом межличностный уровень можно обозначить как определяющий и базовый для всех последующих, поскольку именно безопасность в системе межличностных связей (поддержание устойчивости, целостности межличностных отношений) обеспечивает функционирование и существование остальных уровней. 
Как отмечает И.А. Баева, психологическая безопасность, являясь необходимым условием существования и развития человека и общества, реализуется через определенные формы социальных взаимодействий - совместную деятельность, адаптацию человека и жизненной среды и соблюдение определенных отношений между ними [5]. А. Эдмондсон подчеркивает, что, психологическая безопасность основывается на вере в то, что человек будет принят референтной группой, будет иметь эмоционально благоприятные взаимоотношения и будет защищен от осуждения, неприятия и подавления [5]. Соответственно, психологическая безопасность в межличностных отношениях тем выше, чем лучше люди знают и понимают друг друга в группе [5].

Все сказанное выше дает возможность говорить не просто о психологической безопасности личности, а о ее социально-психологической безопасности (имея ввиду, детерминирующий характер социально-психологических условий обеспечения безопасности человека).

Под социально-психологической безопасностью можно понимать состояние обусловленное наличием гармоничных, приносящих удовлетворение взаимоотношений (взаимосвязей) личности с другими людьми, которые позволяют реализовать духовно-психический потенциал личности в процессе жизнедеятельности, сохранить ее целостность. Основными характеристиками социально-психологической безопасности являются:

- чувство защищенности от негативных психологических воздействий со стороны как партнеров по взаимодействию, так и ситуативных условий;

- отсутствие напряженности, трудностей, нарушений в отношениях;

- гармоничный характер взаимодействий и взаимоотношений.

Поскольку «носителем» социально-психологической безопасности является человек, то можно предположить, что проявления социально-психологической безопасности будут затрагивать основные структуры личности и проявляться через когнитивный, аффективный и поведенческий компоненты. При этом, от того, что думает человек о своем социальном окружении, как его оценивает (какие чувства и переживания испытывает), какие поведенческие стратегии использует, т.е., от того, как он выстраивает всю систему межличностных отношений, и будет зависеть его социально-психологическая безопасность.

Очевидно, что, рассматривая таким образом социально-психологическую безопасность, необходимо обратиться к проблеме межличностных отношений.

Проблема межличностных отношений находит свои истоки еще в философских теориях. Начинаясь (хотя и весьма опосредовано) еще в трудах древнегреческих философов, более полно она затрагивается в трудах философов - экзистенциалистов, где представлена проблема человеческого существования (бытия) как со-существования (со-бытия) человека с Другими, что впоследствии оказало большое влияние на гуманистическую психологию. Идеи сосуществования людей друг с другом и их взаимосвязей остаются одной из актуальных проблем психологической науки. В различных психологических 
школах межличностные отношения определяются по-разному. Следуя традиции отечественной психологической школы, проблема отношений была впервые представлена в исследованиях А.Ф. Лазурского. Отношение, по мнению А.Ф. Лазурского, является системообразующим фактором структуры личности. Отношение личности к внешним объектам и к среде (экзопсихические проявления) наряду с взаимозависимыми психическими элементами и функциями (эндопсихические проявления) характеризуют целостность личности. В разработку концепции психологии отношений большой вклад внес В.Н. Мясищев. Исходным для психологии личности, по В.Н. Мясищеву, является характеристика сущности человека как ансамбля общественных отношений. В свою очередь общественные отношения существуют в двух формах: как объективные отношения и как субъективные отношения. Важное место в системе отношений занимают отношения человека к обществу, общности, коллективу, группе, к самому себе. Самые главные и содержательные отношения складываются в межличностном взаимодействии.

Значительным шагом в развитии психологии отношений является концепция Б.Ф. Ломова. Главное в этой концепции - развернутая характеристика субъективных отношений. Эти отношения отражают ценностные ориентации, привязанности, симпатии, антипатии, интересы, все то, в чем выражается субъективная позиция личности, ее оценка событий, людей, участвующих в них, то, как личность относится к тем или иным событиям и явлениям мира, в котором она живет. Субъективные отношения личности формируются и проявляются, прежде всего, как отношения к людям. Соответственно, отношения ко всем другим сферам действительности опосредуются ими.

Обобщая основные идеи психологии отношений можно подчеркнуть, что в системе социальных связей выделяют общественные и межличностные отношения [1]. При этом общественные отношения - это официальные, формально закрепленные, объективизированные, действенные связи, которые являются ведущими в регулировании всех видов отношений, в том числе и межличностных. Межличностные отношения - это объективно переживаемые, в разной степени осознаваемые взаимосвязи между людьми. В их основе лежат разнообразные эмоциональные состояния взаимодействующих людей. Эмоциональная основа межличностных отношений означает, что они возникают и складываются на основе определенных чувств, рождающихся у людей по отношению друг к другу. Важно подчеркнуть, что межличностные отношения характеризуются трехкомпонентной структурой и включают аффективный, когнитивный (информационный) и поведенческий (практический, регулятивный) компоненты (определяющим из которых является аффективный). Как отмечается в некоторых исследованиях, эмоциональные проявления межличностных отношений обуславливаются социокультурными нормами групп, к которым принадлежат общающиеся, и индивидуальными различиями, варьирующими в пределах этих норм. 
Анализируя связь общественных и межличностных отношений, возникает необходимость говорить о месте общения во всей сложной системе связей человека с внешним миром. Оба ряда отношений человека - и общественные, и межличностные, раскрываются, реализуются именно в общении. Общение и есть реализация всей системы отношений человека. Здесь особенно важно подчеркнуть, что в реальном общении даны не только межличностные отношения людей, т.е. выявляются не только их эмоциональные привязанности, но в общении воплощаются и общественные, т.е. безличные по своей природе, отношения [1].

Эффективность организации процесса общения во многом определяет систему межличностных отношений, а, следовательно - социально-психологическую безопасность людей. Чем выше эффективность общения, тем в большей степени люди чувствуют себя уверенными, целостными; испытывают удовлетворенность, характеризуются отсутствием страха или тревоги; растет их социальная адаптивность, а значит, растет их социально-психологическая безопасность.

Как сложное и многогранное явление, общение потенциально и актуально содержит в себе элементы, затрудняющие уровень его функционирования [4]. Поэтому процесс общения зачастую может протекать не эффективно. В этом случае речь идет о деформации, нарушении общения (различной степени тяжести), что вероятно может приводить к снижению социально-психологической безопасности.

Таким образом, для обеспечения социально-психологической безопасности особое значение приобретает изучение феномена затрудненного общения, различных форм его проявления, психологических детерминант, характера и степени влияния на всю систему межличностных отношений. Анализ этих проблем позволит разработать конкретные практические рекомендации по оптимизации межличностных отношений, что в конечном итоге будет способствовать развитию социально-психологической безопасности личности.

Существуют различные взгляды на феномен трудностей и барьеров общения, на причины и факторы их возникновения, что отражается в разнообразных подходах к их изучению. Под трудностями общения понимаются такие явления, которые возникают в условиях непосредственных контактов, могут быть вызваны различными причинами, как объективными, ситуативными, так и внутренними, личностными и реально проявляются в снижении успешности взаимодействия, в появлении эмоционального и психологического дискомфорта у субъектов общения. Такие явления блокируют резервы духовно-психологического потенциала личности, что нарушает систему его межличностных отношений.

Как подчеркивается в ряде исследований - основной функцией трудностей общения является защита личности от негативного социально-психологического воздействия, что может способствовать ее социально-психологической безопасности. С другой стороны, обеспечивая психологическую защищенность личности, 
эти трудности могут блокировать (затруднять) восприятие и понимание личностью как самого процесса общения (всех его элементов: партнера, ситуации, самого себя), так и межличностных отношений в целом.

В различных исследованиях выделяют мотивационно-содержательные и операциональные трудности, социально-перцептивные и психолингвистические, коммуникативные, внутренние, субъективные и внешние, объективные трудности. Анализ работ показал, что классификации явлений затрудненного общения, основанные на выделении разнообразных причин их возникновения, целесообразны с точки зрения теоретического осмысления данных феноменов. Но при изучении субъекта, переживающего реальную ситуацию затрудненного общения, вычленить отдельные причины, составить представление об их взаимосвязях и совместном обуславливании поведения не представляется возможным.

Наибольший интерес представляют работы, в которых наряду с субъективными трудностями выделяются объективные. Они возникают в условиях непосредственных контактов, могут быть вызваны различными причинами, как объективными, ситуативными, так и внутренними, личностными и реально проявляются в снижении успешности взаимодействия, в появлении эмоционального и психологического дискомфорта у субъектов общения.

Важно подчеркнуть, что такое понимание трудностей позволяет у читывать широкий спектр причин затрудненного общения: от индивидуально-типологических, личностных свойств субъекта до особенностей ситуации взаимодействия. Проведенное нами $[3,6]$ исследование показало, что люди по разному реагируют на возникновение затруднений: проявляют более или менее адекватные реакции, а значит можно предположить, что они имеют разную степень защищенности от неблагоприятных воздействий. У словно можно говорить об их разной социальнопсихологической безопасности. Рассматривая специфику реакций людей в ситуации затрудненного общения можно говорить, что все они носят когнитивный, эмоциональный и поведенческий характер. При этом когнитивный компонент можно изучить только благодаря субъективным самоотчетам участников затрудненного общения. Два других компонента (эмоциональный и поведенческий) могут объективно наблюдаться исследователем.

Таким образом, было показано [3, 6], что по характеру поведенческих и эмоциональных реакций в ситуации затрудненного общения всех людей можно разделить на группы: активных и пассивных (по интенсивности коммуникативного поведения); «стенических» и «астенических» (по содержанию переживаемых эмоций). (При этом полученные данные позволяют утверждать, что связь между характером эмоционального и поведенческого реагирования в ситуации затрудненного взаимодействия не является однозначной.)

Каждую группу характеризуют специфические особенности восприятия и осознания трудностей взаимодействия, разные установки и мотивы общения, тактики коммуникативного поведения, а также разные по содержанию и интенсивности 
изменения психологических и психофизиологических показателей в затрудненном общении. Можно предположить, что эти изменения являются средством компенсации индивидом своей неготовности к налаживанию межличностных отношений. В свою очередь, особенности поведения людей в ситуациях затрудненного общения могут служить показателями их защищенности - незащищенности от негативных воздействий, а следовательно свидетельствовать о наличии - отсутствии социальнопсихологической безопасности.

Сложности в описании «образа» субъекта затрудненного общения вызывают затруднения в разработке коррекционных действий, направленных на стабилизацию процесса общения и гармоничность межличностных отношений. Тем не менее, рассматривая проблему социально-психологической безопасности, важно подчеркнуть необходимость рассмотрения этой категории в прикладном (практическом) контексте защищенности личности от негативного воздействия в ситуациях затрудненного общения, нарушения системы межличностных отношений.

В процессе обеспечения социально-психологической безопасности важно у читывать главный «элемент» любой социальной системы - человека. Известно, что мир представляется человеку в виде объективной и субъективной реальности. Человек преобразует природу и изменяется сам. Наделенный интеллектом, обладая свободой воли, человек совершает действия и интерпретирует факты в силу своего знания и представления о них. Человек одновременно является и субъектом толкования мира, и его объектом [2]. Исходя из этого, выделяют компоненты социальных установок человека, направленных как на самого себя, так и на социум: когнитивный компонент (знания, мнения, суждения, личный опыт, саморефлексии, «всплывающие» в определенных условиях и т.п.); аффективный компонент (чувственно-эмоциональные, субъективные реакции на воздействие факторов, вызывающих переживания, активизирующие или подавляющие человеческую деятельность); поведенческий компонент (действия, операции, поведенческие паттерны, основанные на знании закономерностей предметного мира, причин происходящих в нем изменений).

Поскольку выделенные компоненты соотносятся со структурой социальнопсихологической безопасности (как и структурой межличностных отношений, а также с реакциями людей в ситуациях затрудненного общения), можно предположить, что, развивая и корректируя их, увеличивается вероятность эффективного развития социально-психологической безопасности личности.

В рамках данного исследования представляется, что эти задачи возможно решить посредством обеспечения психологического сопровождения личности. В свою очередь обеспечение психологического сопровождения личности возможно в рамках организации специальной службы социально-психологической безопасности, которая может быть организована в условиях различных образовательных и социальных учреждений, на производстве, промышленных и коммерческих предприятиях, организациях. 
Одной из основных целей подобной службы обеспечения социальнопсихологической безопасности личности может стать проведение диагностической, коррекционно-развивающей, консультативной и просветительской работы с целью повышения психологического здоровья, формирования защищенности и целостности, гармоничности системы межличностных отношений человека.

Формы и методы деятельности службы обеспечения социально-психологической безопасности должны быть направлены на развитие и коррекцию всех компонентов социальных установок личности (когнитивного, аффективного, поведенческого) как показателей устойчивости к различным влияниям извне и собственным негативным переживаниям.

В связи с этим, одними из важных задачами коррекционно-развивающей работы могут стать: формирование навыков эффективного взаимодействия и коммуникативной компетентности; развитие у мения слушать и понимать собеседника; развитие рефлексивных способностей; формирование адекватных поведенческих паттернов в ситуациях затрудненного общения. Поставленные задачи могут быть реализованы в рамках психокоррекционных групп (в частности, групп социально-психологического тренинга), работа которых направлена на развитие коммуникативных навыков и приобретение навыков взаимодействия с другими, развитие уверенного поведения, эффективное преодоление ситуаций затрудненного общения и т.п.

В заключение важно подчеркнуть, что в современных условиях, отличительной чертой которых является неустойчивость социальной системы, у силивается зависимость безопасности социальной системы от компетентности отдельного человека как субъекта социального управления и эффективности обеспечения собственной безопасности. Важно, чтобы действия человека были основаны на анализе сведений о системе межличностных отношений и возможных реакциях на затруднения в общении, а прогноз вероятных последствий принятого решения осуществлялся с учетом взаимосвязи и взаимного влияния всех элементов социальной системы. В связи с этим возрастает необходимость появления центров обеспечения социально-психологической безопасности человека. Причем необходима координация работы подобных центров, как на региональном, так и на государственном и международном уровне.

\section{Литература}

1. Андреева Г.М. Социальная психология. - М. Аспект Пресс, 1998 - 376 с.

2. Информационная безопасность России //Авторский колл. под ред. Ю.С. Уфимцева и Е.А.Ерофеева / http://dvabop.narod.ru/public/public_all.htm.

3. Кузнецова Е.В. Эксакусто Т.В Особенности коммуникативного поведения и эмоциональных переживаний участников затрудненного делового взаимодействия. - Психологический вестник - Вып. 3. - Ростов н/Д: РГУ, 1998. С. $263-274$. 
4. Лабунская В.А. От проблемы затрудненного общения к постановке проблемы «субъект затрудненного общения» // Психологический вестник. - Ростов-на-Дону, 1997. - Вып.2. - Ч. 1. - С. 24-40.

5. Обеспечение психологической безопасности в образовательном учреждении / под ред. Баевой И.А. - СПб.: Речь, 2006. - 288 с.

6. Эксакусто Т.В Специфика изменений некоторых индивидуально-личностных особенностей субъекта в состоянии «барьера» общения. - Материалы Всероссийской научно-практической конференции «Психологический ресурс в экономике и предпринимательстве», Ставрополь, 2002. - С. 204-207. 